\title{
ESTIMASI PARAMETRIK MATERIAL KONSTRUKSI BETON BERTULANG PADA BANTUAN PASKA BENCANA DI ACEH (STUDI KASUS: PERHITUNGAN MATERIAL PONDASI)
}

\author{
Atthaillah \\ Program Studi Arsitektur, Universitas Malikussaleh \\ atthaillah@unimal.ac.id

\section{Eri Saputra} \\ Program Studi Arsitektur, Universitas Malikussaleh \\ erisaputra@unimal.ac.id
}

\begin{abstract}
Abstrak
Penelitian ini merupakan pengembangan dari studi oleh penulis sendiri untuk menciptakan alur kerja yang efektif dan efisien untuk perhitungan kebutuhan material konstruksi pada kasus paska bencana di Aceh. Pada artikel ini penulis fokus pada perhitungan kebutuhan material pondasi. Tujuannya adalah untuk memberikan gambaran yang lebih baik tentang bagaimana sistem yang menjadi proposal kami bekerja. Selain itu, pengembangan kemampuan dari framework sebelumnya juga salah satu hal yang ingin kami dapatkan pada studi ini. Penelitian ini menggunakan metode parametrik dengan Rhinoceros Educational versi 6, Grasshopper3D versi 1 serta GHPython. Rhinoceros digunakan untuk membuat desain. Grasshopper3D digunakan untuk membuat algoritma serta GHPyhton untuk membuat komponen-komponen Grasshopper yang lebih efisien sesuai dengan studi kasus. Pada artikel ini kami juga menggunakan spreadsheet yaitu Microsoft Excel untuk tabulasi data perhitungan. Hasil penelitian ini menunjukkan kemampuan framework berhasil dikembangkan untuk perbandingan alternatif komponen bangunan. Pada kasus ini perbandingan harga material kota Lhokseumawe antara pondasi menerus dan pondasi tapak pada tiga luas bangunan yaitu $55 \mathrm{~m}^{2}, 16 \mathrm{~m}^{2}$ dan $36 \mathrm{~m}^{2}$. Perbandingan tersebut menunjukkan pondasi tapak lebih murah dalam hal material dibandingkan dengan pondasi menerus. Kemampuan ini dinilai penting untuk efektifitas pengambilan keputusan yang relevan dengan konteks paska bencana di daerah tertentu. Kemampuan membandingkan ini juga memberikan peluang untuk peningkatan kondisi psikologis dari penerima atau masyarakat yang terdampak oleh bencana. Hal ini disebabkan oleh adaptabilitas yang tinggi dari framework sehingga bisa disesuaikan dengan kondisi yang diinginkan. Selain itu, kami telah berhasil mengintegrasikan secara efisien pengembangan pada tahap ini ke framework yang sudah dikembangkan sebelumnya.
\end{abstract}

Kata-kata Kunci: parametrik, beton, pasca-bencana, pondasi

\section{PARAMETRIC ESTIMATION FOR REINFORCED CONCRETE CONSTRUCTION MATERIAL IN ACEH POST DISASTER RELIEF (CASE STUDY: ESTIMATION OF FOUNDATION MATERIAL)}

\begin{abstract}
This research was the development of authors' previous work to invent a framework that capable of performing estimation for construction materials effectively and efficiently in Aceh post-
\end{abstract}


disaster cases. In this paper, the writers focus on estimating substructure construction materials. It was aimed at giving a better overview of the proposed framework system. Besides, the improvement of the ability of the previous framework was something that we opted to within this study. This paper employed a parametric method using Rhinoceros Educational version 6, Grasshopper3D version 1 and GHPython. Rhinoceros was used for design making. Grasshopper3D was used to construct algorithms and GHPython was utilized for optimized Grasshopper3D components for efficient workflow. Further, this work utilized spreadsheet, which was Microsoft Excel, for estimation data tabulation. The result showed the abilities of the framework was succeeded to be developed for a new feature, which was comparison capability for building components alternative. In this study, the material price comparison for Lhokseumawe between a continuous rock (rubble stone) and footplate foundations for $55 \mathrm{~m}^{2}, 16 \mathrm{~m}^{2}$, and $36 \mathrm{~m}^{2}$ building area. It was discovered that the footplate foundation cheaper compared to the rubble stone. This capability was significant for an effective decision making in a relevant post-disaster context. The comparison ability had open opportunity to improve the psychological condition for users or societies affected by a disaster. It was due to the high adaptability of the framework to suit specific situations. Besides, we had efficiently integrated the development at this stage successfully to the previous work.

Keywords: parametric, concrete, post-disaster, foundation

\section{Pendahuluan}

Secara konvensional, proses desain dan konstruksi merupakan dua proses yang terpisah dan tidak saling terkait. Kondisi ini memperpanjang waktu total yang dibutuhkan dalam proses konstruksi suatu bangunan. Tahap konstruksi semakin panjang jika terjadi revisi ditahap desain dan harus menunggu selesai proses pertahap. Selanjutnya, setelah segala sesuatu yang berhubungan dengan proses desain selesai dilanjutkan ke tahap perhitungan struktur, mechanical \& electrical $(M E)$, rencana anggaran biaya, proses tender dan tahap konstruksi. Kesemua tahapan tersebut berjalan secara linier sehingga apabila terjadi sesuatu di salah satu tahap maka tahap berikutnya harus ditunda. Hal ini tentunya menciptakan proses desain sampai konstruksi yang tidak efektif dan efisien. Kita membutuhkan hal yang dapat menjembatani hal ini, salah satunya dengan arsitektur digital.

Perkembangan arsitektur digital telah memasuki ranah baru yang mampu meningkatkan efisiensi dan fleksibilitas pada proses desain dan konstruksi bangunan. Teknik-teknik yang dikembangkan pada arsitektur digital dewasa ini memungkinkan proses desain dan konstruksi menjadi proses yang simultan. Hal ini karena kemampuan sharing data desain sekaligus dijadikan data konstruksi (Dunn, 2012). Salah satu teknik yang memungkinkan kemampuan sharing data tersebut adalah metode parametrik.

Terlepas dari minimnya implementasi, teknologi parametrik ini juga menawarkan potensi dan peluang yang bisa dieksplorasi. Potensi-potensi seperti dapat mempersingkat waktu konstruksi, inovasi gambar perencanaan yang lebih mudah, perhitungan volume dan kebutuhan material yang akurat merupakan area-area yang bisa dieksplorasi penerapan teknologi ini pada lingkungan yang low-tech seperti pada kasus paska bencana. Menurut Ashmore, Fowler, \& Kennedy (2008) kurangnya koordinasi dengan logistik, teknikal dan manajerial, ketidakmampuan untuk menghitung dan memastikan kualitas material sebagai akibat dari permintaan yang masif, keinginan yang tidak realistis dari penerima bantuan, kurangnya sumber daya manajemen merupakan beberapa masalah yang ditemui paska bencana gempa dan tsunami di Aceh. Teknologi parametrik sebagaimana diimplementasikan pada penelitian ini dapat menjembatani beberapa permasalahan seperti diungkapkan diatas. Tentunya hal yang langsung dapat dijawab oleh penelitian ini adalah menghitung kebutuhan material dengan cepat dan akurat dengan metode parametrik. 
Selanjutnya, studi ini merupakan perkembangan kajian untuk mengeksplorasi perhitungan kebutuhan material dengan menggunakan algoritma dengan metode parametrik seperti yang telah dijelaskan oleh Atthaillah, Saputra, \& Iqbal (2018). Sebagaimana telah dijelaskan pada studi tersebut konstruksi beton bertulang menjadi tipe konstruksi yang dipilih. Hal ini disebabkan oleh preferensi masyarakat Aceh yang positif terhadap konstruksi beton bertulang. Preferensi konstruksi beton bertulang oleh masyarakat Aceh juga disebabkan oleh peran pemerintah lewat Badan Rekonstruksi dan Rehabilitas Aceh-Nias yang menekankan pada konstruksi ini (da Silva, 2010). Studi ini fokus pada objek pondasi sebagai bahan kajian. Diharapkan dengan fokus pada satu elemen konstruksi bangunan, kita dapat memahami lebih baik proses perhitungan yang dilakukan dengan metode parametrik. Misalnya mengembangkan algoritma untuk dapat membandingkan harga material alternatif pondasi yang digunakan. Hal ini penulis nilai tidak didapatkan pada publikasi kami sebelumnya. Lebih jauh, tujuan kami adalah menciptakan framework yang mampu membuat prototipe dasar, fleksibel dan bisa dikembangkan dengan mudah untuk kebutuhan perhitungan material konstruksi dengan metode parametrik.

\section{Kajian Pustaka}

Definisi terminologi yang digunakan pada kajian ini dapat mengacu pada (Atthaillah et al., 2018). Selanjutnya, untuk dapat memahami perbedaan proses perhitungan dengan menggunakan spreadsheat dan algoritma seperti intensi pada penelitian ini, maka, penulis menilai memiliki urgensi untuk kita bahas disini.

Pertama, Proses kalkulasi atau perhitungan rencana biaya dan kebutuhan material bangunan konstruksi beton bertulang sederhana seringkali menggunakan spreadsheet baik dalam konteks bantuan kemanusiaan maupun dalam konteks privat dan pemerintahan. Dalam prakteknya, kalkulasi dengan spreadsheet seringkali menggunakan data dari gambar kerja 2 (dua) dimensi yang ditabulasikan dalam kedalam software seperti Microsoft Excel dan program-program spreadsheet lainnya. Metode kalkulasi ini merupakan sebuah tahap pekerjaan yang bersifat linier dari tahapantahapan sebelumnya yaitu desain dan gambar kerja. Seringkali dengan metode linier ini pekerjaan tidak dapat dilakukan secara simultan dan tingkat kesalahan data hasil penerjemahan gambar kerja/data 2 (dua) dimensi juga memiliki potensi kesalahan yang tinggi.

Sebagai contoh, jika terjadi perubahan pada desain maka semua proses kalkulasi kebutuhan material harus diulangi dan dicek kembali. Bayangkan jika proses revisi terhadap desain terjadi dalam jumlah yang signifikan, hal ini tentunya memperlambat waktu penyelesaian sebuah proyek. Sementara, dari perspektif desain, sebuah rancangan semakin baik jika telah melalui beberapa perubahan sebagai hasil dari input data yang semakin banyak dan komprehensif. Oleh karena itu, pada kebanyakan kasus perubahan terhadap desain seringkali tidak dapat dielakkan. Konsekuensi waktu tentunya sangat besar pengaruhnya terutama, hal tersebut merupakan proyek pada bantuan kemanusiaan.

Menurut Şener \& Torus (2009), pada bantuan kemanusiaan terutama shelter membutuhkan beberapa kriteria dan target yang harus dicapai yaitu rapidity, efficiency, implementation, material, security, cultural aspect dan psychological condition. Tentunya salah satu faktor yang sangat penting suksesnya kriteria-kriteria tersebut adalah keberhasilan kalkulasi material yang cepat dan akurat. Dengan metode linier menggunakan spreadsheet tentunya sulit untuk mencapai kriteriakriteria tersebut terutama jika ada perubahan-perubahan disalah satu tahap, seperti pada perubahan desain.

Lebih jauh, perhitungan kebutuhan material dengan spreadsheet tidak dapat melihat data yang ditabulasikan dalam bentuk objek realtime tiga dimensi. Sehingga hal ini menyulitkan proses validasi data yang telah ditabulasikan. Ketidak-tersediaannya data yang sedang dihitung secara 3 dimensi ini dapat membuat potensi kesalahan-kesalahan dalam perhitungan yang signifikan. Proses validasi data yang dilengkapi data visual dapat membantu meningkatkan keakuratan hasil 
perhitungan. Sementara pada metode spreadsheet kemampuan ini tidak didapatkan. Metode yang bisa menawarkan kemudahan dan fleksibilitas terhadap kekurangan yang disampaikan diatas bisa diatasi dengan metode parametrik.

Kedua, pendekatan parametrik dapat kita gunakan untuk menghitung kebutuhan material yang lebih efisien dan mengembangkan metode kerja yang lebih efektif dan efisien. Parametrik merupakan sebuah metode yang dapat digunakan untuk memecahkan permasalahan-permasalahan perancangan yang menggunakan algoritma-algoritma sebagai workflow (Atthaillah, 2014). Khabazi (2012) menjelaskan algoritma adalah kumpulan aturan-aturan dan instruksi-instruksi dalam tahapan prosedur tertentu untuk menghitung, memproses data dan melakukan tugas-tugas tertentu yang diberikan. Dengan menggunakan algoritma kita memiliki akses dan peluang yang lebih fleksibel untuk mengembangkan metode-metode kerja atau eksekusi-eksekusi kerja yang lebih optimal. Dalam kasus penelitian ini algoritma dapat kita gunakan untuk mengembangkan metode linier menjadi simultan dan saling terkait antar tahapan dari desain sampai perhitungan kebutuhan material. Dengan demikian waktu yang diperlukan untuk menghitung kebutuhan material bangunan tidak terganggu oleh perubahan-perubahan desain yang terjadi dan mesti terjadi. Hal ini tentunya berkontribusi terhadap efisiensi waktu kerja.

Dengan metode parametrik, integrasi aspek sosial, budaya dan psikologis tidak menjadi permasalahan lagi. Dengan demikian desain dapat dilakukan dengan aspek sosial, budaya dan psikologis secara spesifik untuk lokasi yang berbeda. Hal ini sangat penting untuk kebutuhan bangunan bantuan paska bencana. Penelitian ini juga membuat data dapat divisualkan sehingga memudahkan proses validasi. Hal ini tentunya menjamin keakuratan perhitungan material dari setiap komponen. Tidak hanya itu, metode parametrik ini juga berguna untuk memperbaiki sistem perhitungan untuk kebutuhan tender dan penawaran-penawaran pada proyek privat dan pemerintah. Namun, perhitungan rencana anggaran biaya dalam konteks pemerintahan membutuh modifikasimodifikasi dari penelitian ini untuk dapat diterapkan secara utuh. Sementara untuk konteks konstruksi lainnya membutuhkan studi lanjutan.

Terkait implementasi metode parametrik dilingkungan low-tech, eksplorasi aplikasi teknologi digital dalam konteks kemanusiaan telah dilakukan dalam beberapa fokus yang berbeda. Diantara yang paling awal eksplorasi teknologi digital dilakukan pada tahun 2007 oleh Jinuntuya yang menggunakan dunia 3D virtual untuk mendukung sistem pengambilan keputusan, hal ini dilakukan sebagai pengembangan dari perbaikan dokumentasi yang lebih baik (Jinuntuya dikutip dalam Daher, Kubicki, \& Halin, 2015). Selanjutnya, (Şener \& Torus, 2009) melakukan eksplorasi parametrik dengan menggunakan kontainer untuk membuat kamp pengungsi paska bencana. Kamp yang terbuat dari kontainer tersebut dihasilkan dengan Max Script yang berjalan pada platform 3DSMAX. Dalam penelitian tersebut, konsentrasinya adalah bagaimana membuat kamp yang bisa secara dinamis disusun walaupun jumlah korban tidak diketahui. Hal ini sering terjadi dalam kasus bantuan kemanusiaan pasca bencana. Kemudian fitur lainnya yang ditawarkan adalah kemampuan mengatur kamp secara random sehingga tidak kelihatan monoton seperti banyak terjadi dalam kasus kemanusiaan. Hal ini dinilai bisa meningkatkan performa psikologis dari penerima manfaat, selain itu kontainer juga dapat dibongkar, dipindah dan digunakan kembali pada kasus yang berbeda (Şener \& Torus, 2009). Thikornthanawt dan Jinuntuya pada tahun 2011 melakukan pengembangan antarmuka/interface yang ramah bagi yang bukan pengguna CAD juga telah dilakukan pada proses pembuatan perumahan yang murah. Hal ini memberikan banyak keuntungan untuk bisa mendapatkan input dari berbagai latar belakang yang kemudian diterjemahkan kalkulasi biaya untuk desain perumahan murah (Thikornthanawt dan Jinuntuya dikutip dalam(Daher et al., 2015).

Ada beberapa peneliti lainnya yang telah mencoba melakukannya, hal ini seperti yang pernah penulis bahas pada publikasi sebelumnya diantaranya (Yeung \& Harkins, 2010) pada kasus bencana Solomon Island, (Benros D, Duarte, \& Knight, 2011) pada kasus gempa bumi Haiti dan (Goncalves, 2014) tentang desain alternatif bagi desain shelter (Atthaillah et al., 2018). Dari penelitian tersebut 
fokus pada konstruksi beton bertulang belum ditemukan, sehingga hal ini menjadi penting terutama pada kasus kebencanaan seperti di Aceh. Preferensi masyarakat Aceh terhadap bangunan konstruksi beton bertulang juga meningkatkan urgensi penelitian ini.

\section{Metode Penelitian}

Sebelum melakukan permodelan dengan metode parametrik, kegiatan survey dilakukan untuk mengamati dan memahami tipologi konstruksi beton bertulang untuk bangunan bantuan dibeberapa titik yang tersebar di Aceh. Kegiatan ini berguna untuk menentukan logika permodelan sehingga secara tektonika dan konstruktabilitas bisa mewakili kondisi dari rumah bantuan konstruksi beton bertulang yang ada di Aceh paska bencana.

Selanjutnya, penelitian komputasi dengan teknik parametrik adalah metode yang diintegrasikan pada studi ini. Metode perhitungan yang digunakan pada penelitian ini adalah metode perhitungan dengan algoritma yang merupakan salah satu teknologi parametrik. Algoritma yang dimaksud merupakan algoritma visual yang bekerja pada interface Grasshopper3D. Grasshopper3D merupakan plug-ins yang berjalan pada software Rhinoceros. Kemampuan penulisan algoritma secara visual merupakan hal positif dan keuntungan yang dapat mempermudah desainer dan pengguna yang bahkan belum memiliki latar belakang pemograman sekalipun. Algoritma-algoritma yang disusun dapat memperlihatkan bentuk visual dari objek yang sedang dimodelkan secara realtime. Kemampuan menintegrasikan objek secara visual merupakan hal yang digunakan dalam penelitian ini untuk membantu mempermudah dan mempercepat validasi data-data perhitungan dengan akurat. Kemampuan teknologi parametrik Grasshopper3D ini dinilai sesuai dengan kultur yang ada dalam dunia desain dan arsitektur.

Tahapan-tahapan yang dilakukan pada studi ini masih mengadopsi tahapan yang dilakukan pada studi oleh (Atthaillah et al., 2018). Namun, pada studi lanjutan ini kami menggunakan Rhinoceros Educational versi 6 dan Grasshopper3D versi 1. Pada versi ini, Grasshopper3D sudah terintegrasi dalam Rhinoceros. Ditambah lagi GHPython sudah terintegrasi pada Grasshopper3D, hal ini memudahkan penulis dalam mengembangkan komponen-komponen tambahan dengan GHPython.

Untuk dapat melihat gambaran yang lebih jelas perbedaan antara metode konvensional, yang bersifat linier untuk setiap tahapan desain, dengan metode parametrik yang simultan maka dapat dilihat pada Gambar 1 dan 2. Sementara alur kerja yang digunakan pada metode parametrik yang kami usulkan dapat dilihat pada Gambar 3.

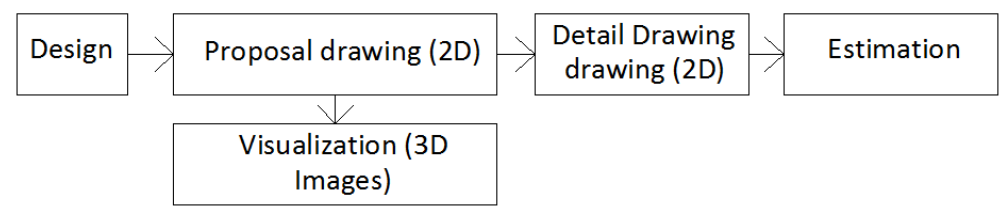

Gambar 1. Proses Pehitungan Dengan Metode Konvensional Sumber: Penulis, 2018

Dari Gambar 1 diatas terlihat proses linier pada metode konvensional. Hal ini menyebabkan data desain tidak sama dengan data perhitungan. Kesalahan seperti salah membaca gambar kerja dari estimator juga menjadi penghambat pada metode ini. Proses bekerja yang linier inilah yang dapat menghambat proses perhitungan kebutuhan material jika terjadi perubahan-perubahan pada desain. Hal ini tentunya menjadi permasalahan terutama pada kasus bantuan kebencanaan yang membutuhkan informasi yang tepat dan akurat. 


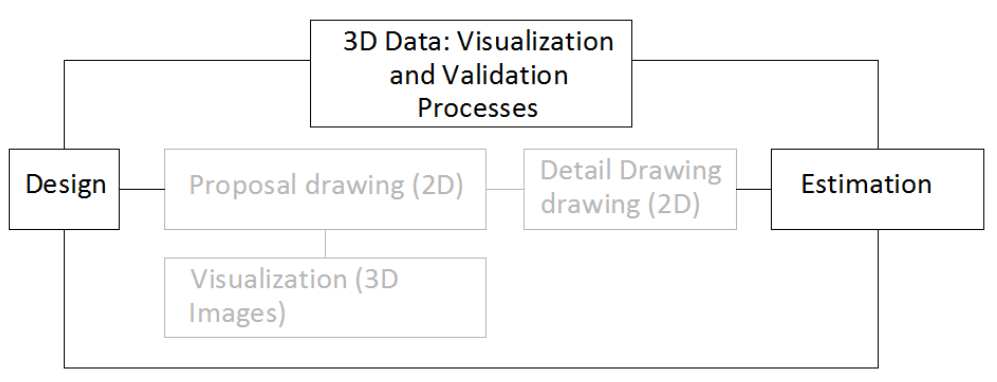

Gambar 2. Proses Pehitungan Dengan Metode Parametrik Sumber: Penulis, 2018

Pada penelitian ini kami mengusulkan perhitungan dengan metode parametrik yang memiliki proses yang simultan. Gambar 2 menunjukkan proses bekerja yang simultan dari metode parametrik. Pada metode ini data desain sama dengan data perhitungan, hal ini tentunya mempercepat sekaligus memberikan hasil yang akurat karena data desain bisa digunakan sebagai data perhitungan kebutuhan material. Pada penelitian ini alur kerja yang kami usulkan seperti pada Gambar 3 berikut.

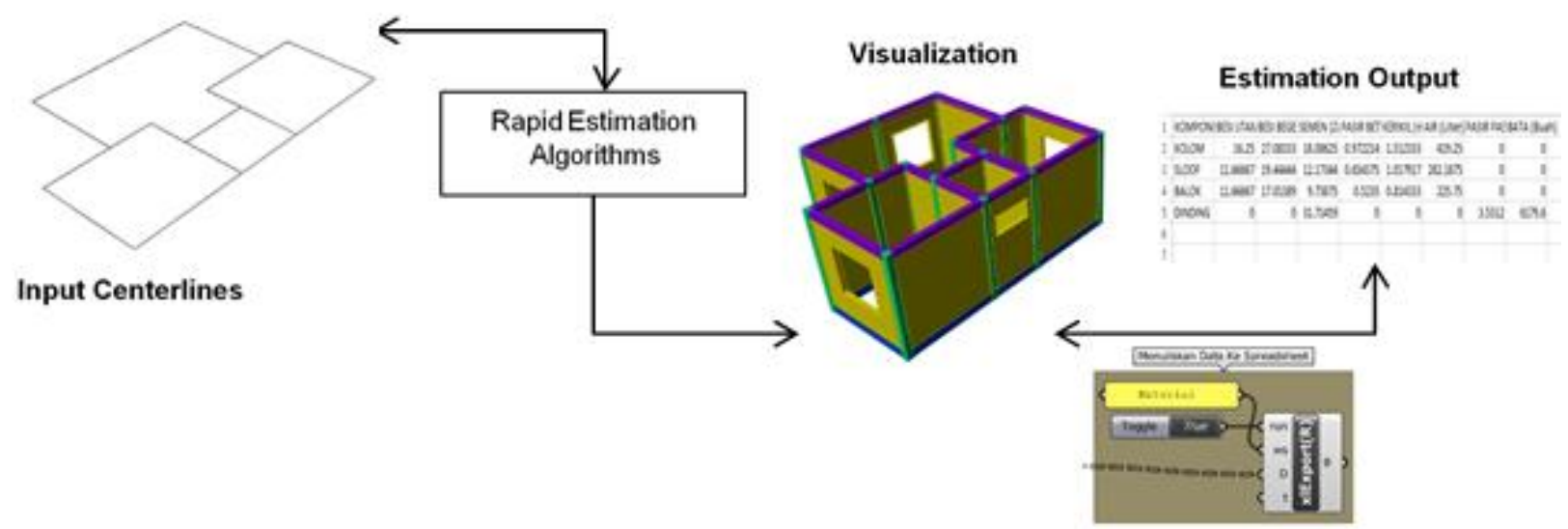

Gambar 3. Alur Kerja Metode Parametrik

Sumber: Atthaillah et al., 2018

Selanjutnya proses validasi pada studi ini menggunakan (SNI 7394, 2008), untuk pekerjaan beton dan bekisting. Sementara kebutuhan besi dihitung berdasarkan hasil permodelan sistem perakitan besi khusus pada pondasi tapak. Hal tersebut dilakukan dengan menghitung panjang besi utama dan besi sengkang secara otomatis berdasarkan hasil permodelan. Kebutuhan material untuk pondasi menerus kami gunakan (SNI 2836, 2008). Dengan cara ini proses permodelan dan validasi pondasi sampai perhitungan kebutuhan material pondasi dilakukan. Adapun pondasi yang kami fokuskan pada tahap ini adalah pondasi tapak dan menerus. Kedua, jenis pondasi ini lazim dipakai pada konstruksi rumah-rumah bantuan yang kami survey. Data teknis pondasi yang kami modelkan dapat dilihat pada Gambar 4 berikut. 


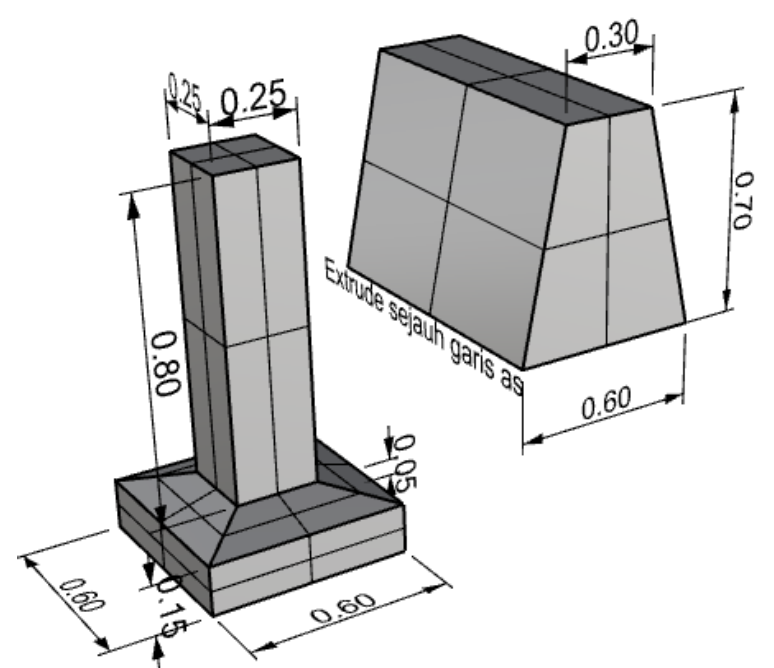

Gambar 4. Detail Pondasi Tapak Dan Menerus Pada Studi Ini Sumber: Penulis, 2018

Pada penelitian ini kami masih mengabaikan ongkos tukang dan fokus pada material yang harus dibeli khusus pada geometri pondasi yang dimodelkan. Hal ini karena keberhasilan algoritma sangat ditentukan oleh keberhasilan melakukan permodelan ini. Sebagai tambahan, hal ini juga merupakan hal tersulit dalam menyusun algoritma pada studi ini. Pekerjaan galian dan timbunan yang merupakan lingkup pekerjaan pondasi tidak menjadi fokus kami. Jika dibutuhkan pekerjaan ini dan lainnya yang terkait dengan pondasi dapat diintegrasikan dengan mudah jika sistem yang menjadi proposal pada penelitian ini sudah berjalan.

\section{Hasil dan Pembahasan}

Perlu kami jelaskan pada tahap sebelumnya algoritma sudah dapat melakukan proses permodelan, visualisasi, dan perhitungan untuk kolom, dinding, sloof dan balok seperti ditunjukkan pada Gambar 5 dan hasil permodelan dan perhitungan pada Gambar 6. Untuk permodelan pondasi tapak, data diambil dari jumlah titik kolom pada bangunan. Sementara jumlah kolom ditentukan oleh aturan jika luas dinding mencapai $12 \mathrm{~m}^{2}$, maka algoritma membuat kolom tambahan. Untuk pondasi menerus sebagaimana telah dijelaskan sebelumnya kami menggunakan garis as yang digunakan sebagai input algoritma.

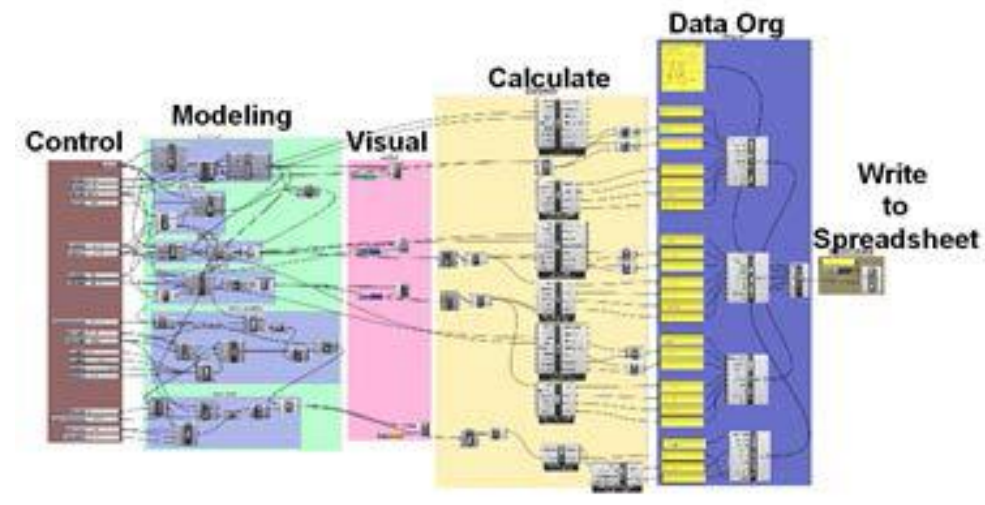

Gambar 5. Algoritma Permodelan, Visualisasi Dan Perhitungan Untuk Kolom, Sloof, Balok Dan Dinding

Sumber: Atthaillah et al., 2018 


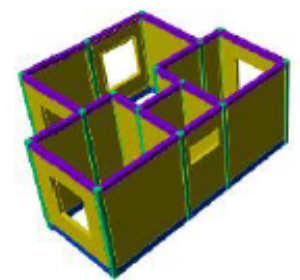

\begin{tabular}{|l|r|r|r|r|r|r|r|r|}
\hline KOMPONEN & $\begin{array}{c}\text { BESI UTAMA } \\
\text { (Batang) }\end{array}$ & $\begin{array}{c}\text { BESI BEGEL } \\
\text { (Batang) }\end{array}$ & $\begin{array}{c}\text { SEMEN } \\
\text { (Zak) }\end{array}$ & $\begin{array}{c}\text { PASIR } \\
\text { BETON (m3) }\end{array}$ & $\begin{array}{c}\text { KERIKIL } \\
\text { (m3) }\end{array}$ & AIR (Liter) & $\begin{array}{c}\text { PASIR } \\
\text { PASANG } \\
\text { (m3) }\end{array}$ & BATA (Buah) \\
\hline KOLOM & 16.25 & 27.083333 & 18.08625 & 0.972214 & 1.512333 & 419.25 & 0 & 0 \\
\hline SLOOF & 11.666667 & 19.444444 & 12.173437 & 0.654375 & 1.017917 & 282.1875 & 0 & 0 \\
\hline BALOK & 11.666667 & 17.013889 & 9.73875 & 0.5235 & 0.814333 & 225.75 & 0 & 0 \\
\hline DINDING & 0 & 0 & 31.71459 & 0 & 0 & 0 & 3.5312 & 6179.6 \\
\hline
\end{tabular}

Area: $38.40 \mathrm{~m} 2$

Gambar 6. Hasil Algoritma Sebelum Mampu Memodelkan Pondasi Sumber: Atthaillah et al., 2018

Terkait fokus penelitian pada artikel ini, dari data survey, menunjukkan ada dua sistem pondasi yang diterapkan pada pada rumah bantuan yang menjadi objek studi pada penelitian ini. Pertama, pondasi menerus yang lazim digunakan pada rumah bantuan yang kami dapatkan. Kedua, pondasi setempat atau pondasi tapak yang sedikit sekali digunakan pada rumah bantuan dengan konstruksi beton bertulang di Aceh. Pada tahap ini untuk permodelan pondasi menerus masih mengalami masalah dalam menyusun algoritma sehingga belum berhasil dimodelkan dan divisualkan. Namun, perhitungan kebutuhan material pondasi menerus dapat dihitung dengan mengacu pada (SNI 2836, 2008) sebagai acuan koefisien material yang digunakan. Pada studi ini kami menggunakan pondasi menerus dengan campuran 1PC (Portland cement): 4PP (pasir pasang) sebagaimana banyak dijumpai pada objek studi. Kami membuat bentuk pondasi menerus imajiner dengan bentuk visual seperti pada Gambar 4 diatas. Luas dari pondasi tersebut kemudian dikalikan dengan panjang garis as yang menjadi input dari algoritma. Dengan demikian volume pondasi menerus diperoleh. Dimensi pondasi menerus juga dimungkinkan untuk diubah-ubah sesuai dengan kebutuhan pondasi pada suatu daerah. Hal ini tergantung dari kondisi tanah pada lokasi yang berbeda. Algoritma perhitungan material pondasi menerus dapat dilihat pada Gambar 7. Pada tahap ini untuk pondasi menerus belum ada data yang berhasil divisualkan.

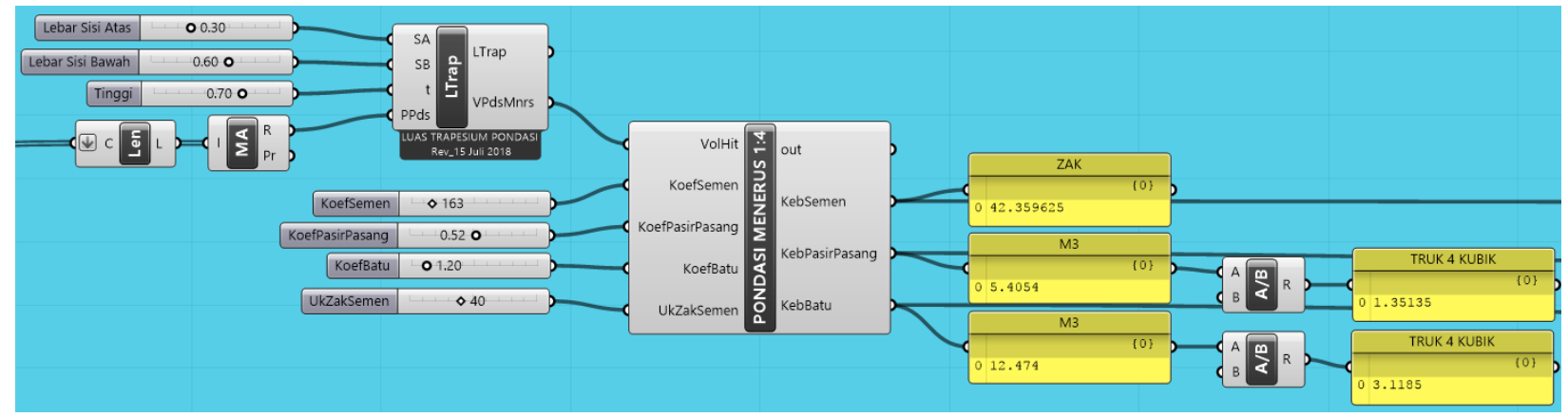

Gambar 7. Algoritma Perhitungan Kebutuhan Material Pondasi Menerus Sumber: Penulis, 2018

Untuk pondasi tapak kami telah berhasil membuat model, visualisasi dan menghitung kebutuhan material. Ada tiga bagian algoritma untuk permodelan pondasi tapak. Pertama, permodelan keseluruhan pondasi tapak, data ini digunakan untuk visualisasi dan menghitung kebutuhan material pembuatan beton pondasi. Kedua, permodelan tapak pondasi saja, hal ini digunakan untuk memodelkan dan menghitung kebutuhan pembesian pada pondasi tapak. Pemisahan ini dilakukan untuk memudahkan proses permodelan dan validasi yang disebabkan oleh perbedaan karakter geometri antara tapak dan pedestal. Ketiga, permodelan pedestal saja, ini 
dilakukan untuk membuat permodelan pembesian pada tiang pedestal pondasi. Dengan cara seperti ini perhitungan kebutuhan besi pada pondasi tapak dapat dihitung dengan mudah. Sampai tahap ini algoritma sudah bekerja secara fleksibel, simultan dan otomatis. Alterasi pada pondasi tidak akan menambah waktu perencanaan dan perhitungan karena pada tahap ini algoritma telah menunjukkan kemampuan sharing data antara pemodelan dengan perhitungan kebutuhan material konstruksi. Pada tahap ini algoritma berhasil dikembangkan kemampuannya seperti ditunjukkan pada Gambar 8 . Kata kunci yang digunakan pada gambar tersebut menunjukkan kemampuan framework. Sementara, permodelan pembesian pondasi tapak seperti telah dijelaskan diatas ditunjukkan pada Gambar 9.

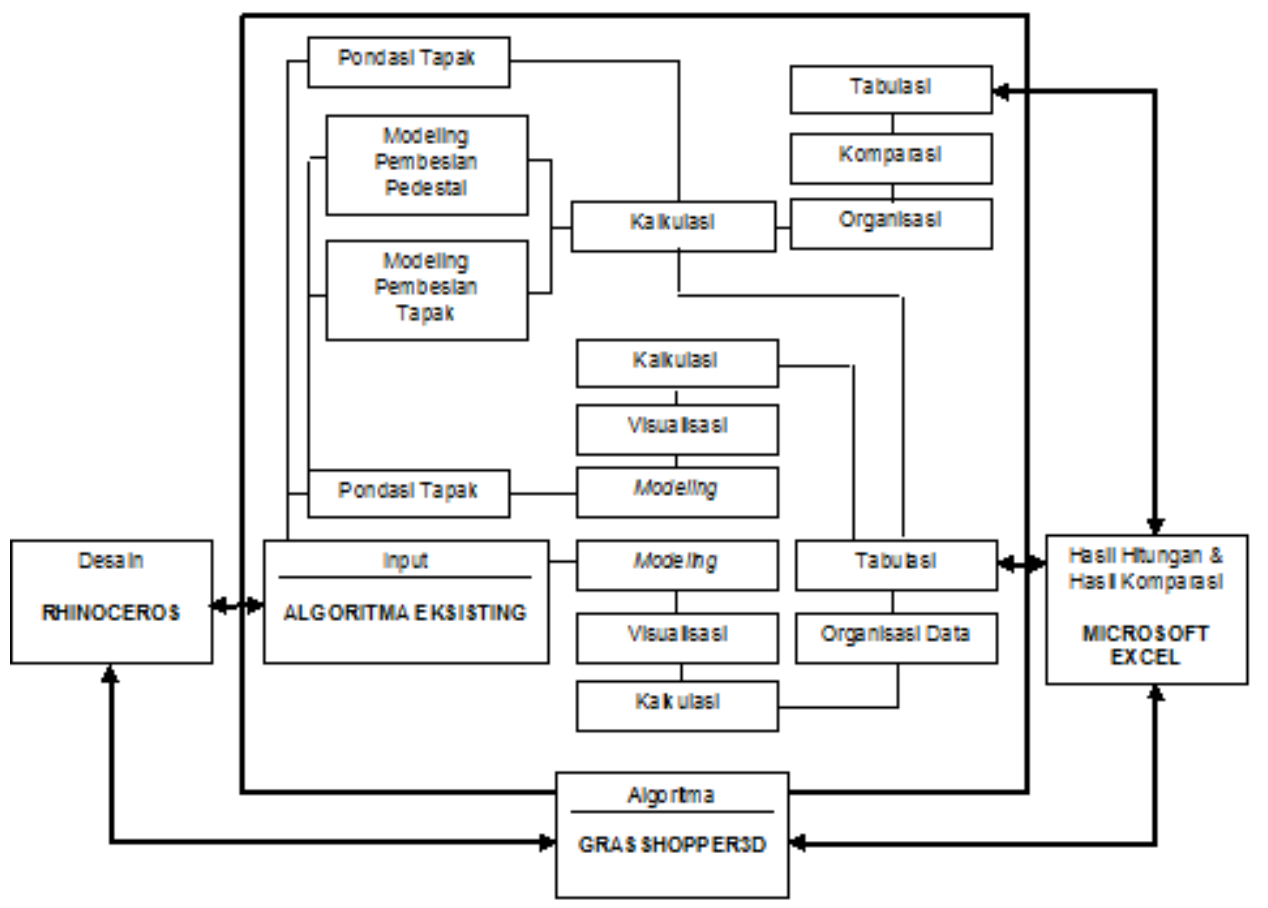

Gambar 8. Kemampuan Algoritma Yang Sudah Dikembangkan

Sumber: Penulis, 2018

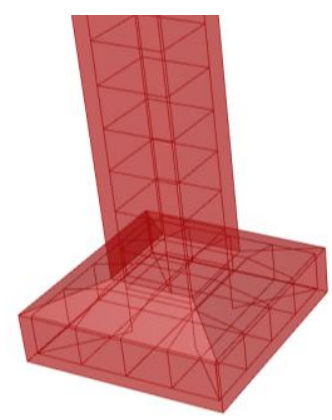

Gambar 9. Hasil Permodelan Pembesian Pada Pondasi Tapak Untuk Perhitungan Kebutuhan Besi Sumber: Penulis, 2018

Walaupun ukuran pondasi dapat disesuaikan dengan kondisi daerah tertentu, namun, hal itu tidak membuat proses perhitungan terganggu. Dengan algoritma pada studi kami, perubahan data dapat dimutakhirkan tanpa ada jeda waktu karena proses perhitungan dilakukan secara otomatis. Hal ini sangat bermanfaat ketika diimplementasikan pada kasus bantuan rumah bencana yang kondisi lokasi tidak dapat diprediksi secara akurat. Hal ini tentunya dapat membantu proses perencanaan untuk rumah bantuan paska bencana. 
Tersedianya alternatif pondasi seperti telah dijelaskan sebelumnya, maka penulis mengembangkan algoritma untuk dapat membandingkan harga material yang dipakai baik untuk pondasi menerus maupun tapak. Kemampuan ini sangat penting untuk membantu pengambilan keputusan yang sesuai dengan biaya dan kondisi lapangan pada konteks paska bencana. Dengan cara seperti ini akan membantu mempercepat pengambilan keputusan walaupun dengan berbagai alternatif ukuran dan jenis pondasi. Sering kali pada kasus paska bencana seperti di Aceh, yang mengerjakan rumah bantuan adalah pemilik atau tukang setempat. Hal ini penting untuk diberi ruang karena dinilai dapat meningkatkan parameter-parameter yang disebutkan oleh Şener \& Torus, (2009). Lazim terjadi kemampuan tukang yang tersedia harus diadaptasikan dengan model pondasi tertentu walaupun opsi pondasi tertentu lebih murah. Setidaknya dengan algoritma ini selisih harga dapat ditentukan dengan cepat, sehingga untuk lokasi yang berbeda dengan solusi desain yang berbeda tidak memperanguhi waktu perhitungan kebutuhan material. Perbandingan harga pondasi dituliskan secara otomatis kedalam spreadsheet. Hal ini dimaksudkan karena data tersebut tidak hanya digunakan oleh kalangan teknis saja, namun juga kalangan non-teknis yang terlibat pada paska bencana.

Sampai tahap ini, algoritma sudah diintergrasikan ke framework pada penelitian kami sebelumnya dan ditambahkan dengan kemampuan membandingkan harga dari alternatif pondasi yang digunakan. Hasil perhitungan yang sampai saat ini telah berhasil dituliskan ke spreadsheet dapat dilihat pada Gambar 10. Pada gambar tersebut bagian struktur atas sengaja tidak divisualkan berwarna untuk meng-highlight bagian pondasi yang menjadi perkembangan pada tahap ini. Sementara, hasil perhitungan perbandingan harga pada pemilihan pondasi tapak dan menerus dapat dilihat pada Gambar 11.

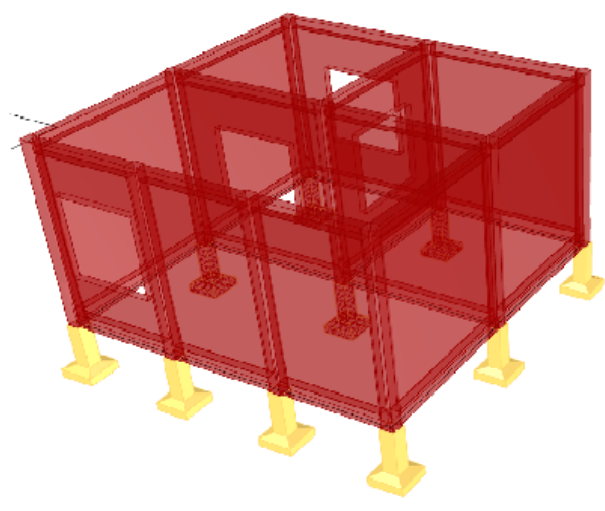

\begin{tabular}{l|r|r|r|r|r|r|r|r|} 
KOMPONEN & $\begin{array}{c}\text { BESI } \\
\text { UTAMA } \\
\text { (Batang) }\end{array}$ & $\begin{array}{c}\text { BESI } \\
\text { BEGEL } \\
(\text { Batang })\end{array}$ & $\begin{array}{c}\text { SEMEN } \\
(\text { Zak })\end{array}$ & $\begin{array}{c}\text { PASIR } \\
\text { BETON } \\
(\mathrm{m} 3)\end{array}$ & $\begin{array}{c}\text { KERIKIL } \\
(\mathrm{m} 3)\end{array}$ & $\begin{array}{c}\text { AIR } \\
(\text { Liter })\end{array}$ & $\begin{array}{c}\text { PASIR } \\
\text { PASANG } \\
(\mathrm{m} 3)\end{array}$ & $\begin{array}{c}\text { BATA } \\
\text { (Buah) }\end{array}$ \\
\hline KOLOM & 11.333333 & 18.88889 & 12.614 & 0.678057 & 1.054756 & 292.4 & 0 & 0 \\
\hline SLOOF & 10.2 & 17 & 10.64306 & 0.572111 & 0.88995 & 246.7125 & 0 & 0 \\
\hline BALOK & 10.2 & 14.875 & 8.51445 & 0.457689 & 0.71196 & 197.37 & 0 & 0 \\
\hline DINDING & 0 & 0 & 28.93759 & 0 & 0 & 0 & 3.222 & 5638.5 \\
\hline PONDASI TAPAK & 19.367836 & 6 & 10.53099 & 0.566086 & 0.880579 & 244.1147 & 0 & 0 \\
\hline
\end{tabular}

Gambar 10. Hasil Permodelan, Visualsisasi Dan Perhitungan Kebutuhan Material Pondasi Dan Material Komponen Bangunan Diatas Tanah

Sumber: Penulis, 2018

Dari hasil perbandingan pada berbagai luasan bangunan yang dimodelkan dengan algoritma, kami mendapatkan bahwa harga material untuk pondasi tapak lebih murah untuk semua luasan bangunan yang kami bandingkan. Harga material yang menjadi acuan adalah harga pasaran di Lhokseumawe dimana penulis berdomisili. Untuk daerah lain harga dapat dimutakhirkan dengan mudah pada algoritma ini. Selanjutnya, perlu kami sampaikan yang kami bandingkan hanyalah harga material saja tanpa ongkos tukang. Perbandingan kesemua luas konstruksi yang kami bandingkan dapat dilihat pada Gambar 11. Perlu kami jelaskan kesemua perbandingan ini dimodelkan, divisualkan dan dihitung membutuhkan waktu kurang dari satu menit. 


\begin{tabular}{|c|c|c|c|c|c|c|c|c|c|c|}
\hline \multirow{2}{*}{$\begin{array}{l}\text { NAMA MATERIAL } \\
\text { BESI UTAMA (Batang) }\end{array}$} & \multirow{2}{*}{\begin{tabular}{|r|} 
PONDASI \\
MENERUS \\
0 \\
\end{tabular}} & \multicolumn{2}{|r|}{ HARGA } & \multicolumn{2}{|r|}{$\begin{array}{c}\text { KEB MAT X } \\
\text { HARGA } \\
\end{array}$} & \multirow{2}{*}{$\begin{array}{c}\begin{array}{c}\text { PONDASI } \\
\text { TAPAK }\end{array} \\
25.178191\end{array}$} & \multicolumn{2}{|r|}{ HARGA } & \multicolumn{2}{|r|}{$\begin{array}{l}\text { KEB MAT } x \\
\text { HARGA } \\
\end{array}$} \\
\hline & & $\mathrm{Rp}$ & $87,000.00$ & $\mathrm{RP}$ & - & & $\mathrm{Rp}$ & $87,000.00$ & $\mathrm{Rp}$ & $2,190,500.00$ \\
\hline BESI BEGEL (Batang) & 0 & $\mathrm{Rp}$ & $30,000.00$ & $\mathrm{Rp}$ & - & 7.8 & $\mathrm{Rp}$ & $30,000.00$ & $\mathrm{Rp}$ & $234,000.00$ \\
\hline SEMEN (Zak) & 47.494125 & $\mathrm{Rp}$ & $53,000.00$ & $\mathrm{Rp}$ & $2,517,200.00$ & 13.69029 & $\mathrm{Rp}$ & $53,000.00$ & $\mathrm{Rp}$ & $725,585.35$ \\
\hline PASIR BETON (m3) & 0 & $\mathrm{Rp}$ & $130,000.00$ & $\mathrm{Rp}$ & p - & 0.735912 & $\mathrm{Rp}$ & $130,000.00$ & $\mathrm{Rp}$ & $95,668.61$ \\
\hline KERIKIL (m3) & 0 & $\mathrm{Rp}$ & $145,000.00$ & $\mathrm{Rp}$ & - & 1.144753 & $\mathrm{Rp}$ & $145,000.00$ & $\mathrm{Rp}$ & $165,989.12$ \\
\hline AIR (Liter) & 0 & $\mathrm{Rp}$ & 100.00 & $\mathrm{Rp}$ & - & 0 & $\mathrm{Rp}$ & 100.00 & $\mathrm{Rp}$ & - \\
\hline PASIR PASANG (m3) & 6.0606 & $\mathrm{Rp}$ & $130,000.00$ & $\mathrm{Rp}$ & $787,878.00$ & 0 & $\mathrm{Rp}$ & $130,000.00$ & $\mathrm{Rp}$ & - \\
\hline BATA (Buah) & 0 & $\mathrm{Rp}$ & 500.00 & $\mathrm{Rp}$ & - & 0 & $\mathrm{Rp}$ & 500.00 & $\mathrm{Rp}$ & - \\
\hline \multirow[t]{2}{*}{ BATU POND (M3) } & 13.986 & $\mathrm{Rp}$ & $160,000.00$ & & p $2,237,800.00$ & 0 & $\mathrm{Rp}$ & $160,000.00$ & $\mathrm{Rp}$ & - \\
\hline & & & & & p $5,542,900.00$ & & & & Rp & $3,411,700.00$ \\
\hline
\end{tabular}

\begin{tabular}{|c|c|c|c|c|c|c|c|c|c|c|}
\hline \multirow{2}{*}{$\frac{\text { NAMA MATERIAL }}{\text { BESI UTAMA (Batang) }}$} & \multirow{2}{*}{$\begin{array}{r}\text { PONDASI } \\
\text { MENERUS } \\
0 \\
\end{array}$} & \multicolumn{2}{|r|}{ HARGA } & \multicolumn{2}{|c|}{$\begin{array}{l}\text { KEB MAT X } \\
\text { HARGA }\end{array}$} & \multirow{2}{*}{$\begin{array}{l}\begin{array}{l}\text { PONDASI } \\
\text { TAPAK }\end{array} \\
15.494257\end{array}$} & \multicolumn{2}{|r|}{ HARGA } & \multicolumn{2}{|r|}{$\begin{array}{l}\text { KEB MAT } x \\
\text { HARGA }\end{array}$} \\
\hline & & $\mathrm{Rp}$ & $87,000.00$ & $\mathrm{Rp}$ & - & & $R p$ & $87,000.00$ & $\mathrm{Rp}$ & $1,348,000.00$ \\
\hline BESI BEGEL (Batang) & 0 & $\mathrm{Rp}$ & $30,000.00$ & $\mathrm{Rp}$ & - & 4.8 & $\mathrm{Rp}$ & $30,000.00$ & $\mathrm{Rp}$ & $144,000.00$ \\
\hline SEMEN (Zak) & 20.538 & $\mathrm{Rp}$ & $53,000.00$ & $\mathrm{Rp} 1$ & $1,088,500.00$ & 8.424789 & $\mathrm{Rp}$ & $53,000.00$ & $\mathrm{Rp}$ & $446,513.79$ \\
\hline PASIR BETON (m3) & 0 & $\mathrm{Rp}$ & $130,000.00$ & $\mathrm{Rp}$ & - & 0.452869 & $\mathrm{Rp}$ & $130,000.00$ & $\mathrm{Rp}$ & $58,872.95$ \\
\hline KERIKIL (m3) & 0 & $\mathrm{Rp}$ & $145,000.00$ & $\mathrm{Rp}$ & - & 0.704463 & $\mathrm{Rp}$ & $145,000.00$ & $\mathrm{Rp}$ & $102,147.09$ \\
\hline AIR (Liter) & 0 & $\mathrm{Rp}$ & 100.00 & $\mathrm{Rp}$ & - & 0 & $\mathrm{Rp}$ & 100.00 & $\mathrm{Rp}$ & - \\
\hline PASIR PASANG $(\mathrm{m} 3)$ & 2.6208 & $\mathrm{Rp}$ & $130,000.00$ & $\mathrm{Rp}$ & $340,704.00$ & 0 & $\mathrm{Rp}$ & $130,000.00$ & $\mathrm{Rp}$ & - \\
\hline BATA (Buah) & 0 & $\mathrm{Rp}$ & 500.00 & $\mathrm{Rp}$ & - & 0 & $\mathrm{Rp}$ & 500.00 & $\mathrm{Rp}$ & - \\
\hline \multirow[t]{2}{*}{ BATU POND (M3) } & 6.048 & $\mathrm{Rp}$ & $160,000.00$ & & $967,680.00$ & 0 & $\mathrm{Rp}$ & $160,000.00$ & $\mathrm{Rp}$ & - \\
\hline & & & & Rp 2 & $2,396,900.00$ & & & & $\mathrm{Rp}$ & $2,099,500.00$ \\
\hline
\end{tabular}

Luas Bangunan $=16 \mathrm{~m}^{2}$

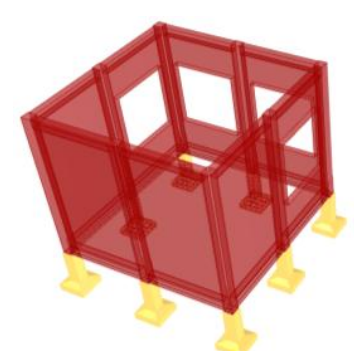

Luas Bangunan $=36 \mathrm{~m}^{2}$

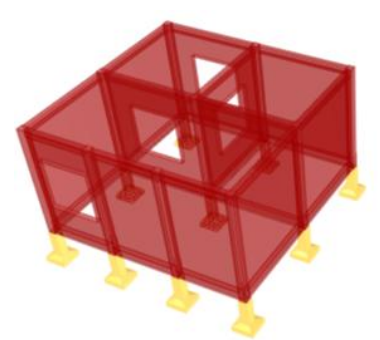

Gambar 11. Perbandingan Harga Pondasi Pada Berbagai Luas Bangunan

Sumber: Penulis, 2018

\section{Kesimpulan}

Pada studi ini, kemampuan framework seperti telah disimpulkan oleh (Atthaillah et al., 2018) telah berhasil dikembangkan kemampuannya untuk membandingkan alternatif pondasi yang dipilih terkait konteks tertentu. Kemampuan untuk membandingkan ini tidak menjadi perhatian kami sebelumnya. Hal ini muncul disebabkan ada alternatif pondasi yang ditemukan sehingga perlu dibandingkan sebelum keputusan final diambil untuk konstruksi. Selanjutnya, pada penelitian ini juga berhasil membuktikan integrasi algoritma pondasi ke framework sebelumnya dengan mudah dan efisien. Tentunya hal ini akan membuat framework ini mudah dikembangkan sesuai dengan keperluan yang spesifik. Contohnya, jika diperlukan untuk keperluan perhitungan biaya pada proyek pemerintah tentunya dengan alterasi-alterasi sesuai dengan format yang dipakai dipemerintahan.

Lebih jauh, kemampuan membandingkan pondasi ini penulis nilai dapat meningkatkan nilai yang disebutkan oleh Şener \& Torus (2009). Hal ini dibuktikan dengan adaptabilitas dari framework 
yang tinggi untuk disesuaikan dengan kondisi tertentu pada kasus kebencanaan. Misalnya, kemampuan tukang setempat yang hanya bisa membuat pondasi menerus, dengan algoritma bisa dengan cepat dibuat alternatif kebutuhan material. Penyesuaian kondisi seperti ini dianggap signifikan dalam konteks kebencanaan karena dinilai dapat meningkatkan kondisi psikologis. Dalam kasus ini efisiensi harus dipertaruhkan untuk peningkatan kondisi psikologis para korban. Efektifitas pengambilan keputusan juga bisa ditingkatkan dengan kemampuan membandingkan ini.

\section{Daftar Pustaka}

Ashmore, J., Fowler, J., \& Kennedy, J. (2008). IASC Emergency Shelter Cluster Shelter Projects. UnSpecified: UN-HABITAT.

Atthaillah. (2014). Arsitektur parametrik dengan Rhinoceros dan Grasshopper: Kajian workflow dari desain, fabrikasi hingga hitungan kebutuhan material. Arsitekno, 3, 10-23.

Atthaillah, E., Saputra, \& Iqbal, M. (2018). Parametric Estimation for Reinforced Concrete Relief Shelter for Aceh Cases. In IOP Conf. Series: Materials Science and Engineering 352 (p. 012061). IOP Science. https://doi.org/10.1088/1757899X/352/1/012061

Benros D, G., Duarte, J. P., \& Knight, T. (2011). Automated design and delivery of relief housing: the case of post-earthquake Haiti. In Proceeding of the 14th International Conference on Computer Aided Architectural Design (pp. 247264). Liege.

da Silva, J. (2010). Lessons from Aceh: Key Considerations in Post-Disaster Reconstruction. Warwickshire: Practical Action Publishing.

Daher, E., Kubicki, S., \& Halin, G. (2015). parametric process for shelters and refugees' camps design.
In Proceedings of the 33rd International eCAADe (pp. 541-548). Vienna.

Dunn, N. (2012). Digital Fabrication in Architecture. London: Laurence King Publishing.

Goncalves, A. M. d C. F. A. (2014). A Grammar for Shelter: An exploration of ruled based designs $n$ prefabricated and modular shelters. In Proceeding of the 32nd International eCAADe (pp. 327-336). Newcastle.

Khabazi, Z. (2012). Generative Algorithm using Grasshopper. Morphogenesism.

Şener, S. M., \& Torus, B. (2009). Container Post Disaster Shelter-CPoDS (pp. 599-604). Proceedings of eCAADe 27.

SNI 2836, A. (2008). Tata cara perhitungan harga satuan pekerjaan pondasi untuk konstruksi bangunan gedung dan perumahan. Jakarta: Badan Standardisasi Nasional.

SNI 7394, A. (2008). Tata cara perhitungan harga satuan pekerjaan beton untuk konstruksi bangunan gedung dan perumahan. Jakarta: Badan Standardisasi Nasional.

Yeung, W. K., \& Harkins, J. (2010). Digital architecture for humanitarian design in postdisaster reconstruction. International Journal of Architectural Computing, 9, 17-31. 